玹

JOURNAL OF ETHNOBIOLOGY

AND ETHNOMEDICINE

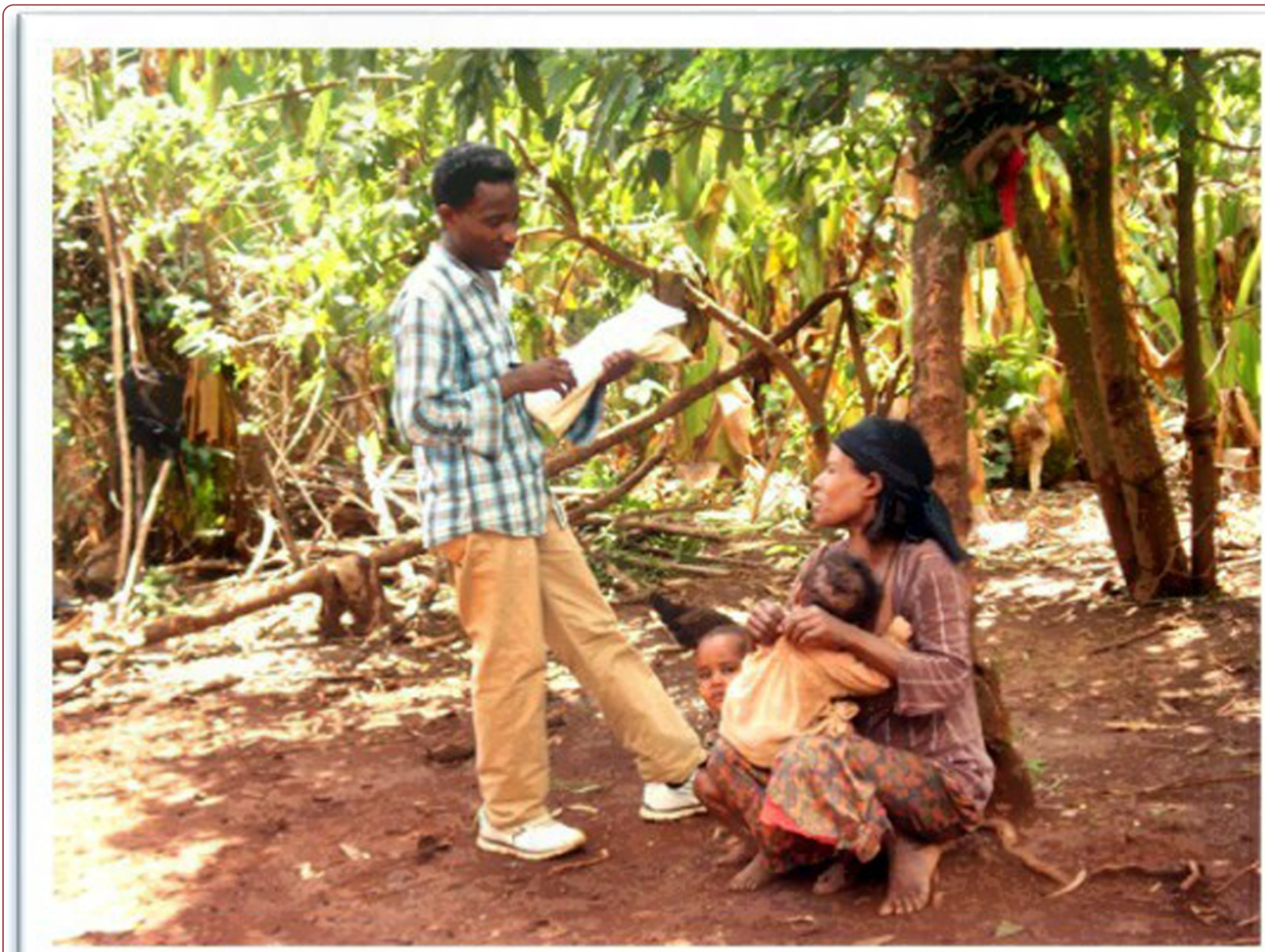

Insect repellent plants traditional usage practices in the Ethiopian malaria epidemic-prone setting: an ethnobotanical survey

Karunamoorthi and Hailu

C Biomed Central 


\title{
Insect repellent plants traditional usage practices in the Ethiopian malaria epidemic-prone setting: an ethnobotanical survey
}

\author{
Kaliyaperumal Karunamoorthi ${ }^{*}$ and Teklu Hailu
}

\begin{abstract}
Background: The usage of insect repellent plants (IRPs) is one of the centuries-old practices in Africa. In Ethiopia, malaria remains a leading cause of morbidity and mortality, subsequently the majority of people have a tendency to apply various plants as repellents to reduce or interrupt the biting activity of insects. Accordingly, this survey was undertaken to document and evaluate knowledge and usage practices of the local inhabitants on IRPs in the malaria epidemic-prone setting of Ethiopia.
\end{abstract}

Methods: Ethnobotanical survey was conducted between January and May 2013. Selected 309 household members were interviewed by administering pre-tested questionnaire on knowledge and usage practices of repellent plants, in Bechobore Kebele, Jimma Zone, Ethiopia.

Results: Overall, 70.2\% (217/309) and 91.8\% (199/217) of the respondents have had ample awareness and usage practices of repellent plants, respectively. Informants cited about twenty-two plant species as repellents and also indicated that these plants are useful(85.5\%), accessible(86.8\%), and affordable(83.9\%) too. Residents mainly applying dried leaves [93.9\% (187/199)] by means of burning/smouldering [98.9\% (197/199)] with the traditional charcoal stove to repel insects, primarily mosquitoes. About 52.8\% (105/199) of the informants using aproximately $15 \mathrm{~g}$ of dried plant-materials every day. A Chi-square analysis shows statistically a significant link between the knowledge on repellent plants and gender as well as average monthly income although not with the age of the respondents. Nevertheless, the repellent plant usage custom was not significantly associated with gender, monthly income, and age of the informants.

Conclusion: Though most of the people have had an adequate awareness still a sizable faction of society suffers with deprivation of IRPs knowledge and usage practices. Therefore, this study calls for more surveys to conserve the existing indigenous knowledge and cultural practices. It could lay the first stone to develop the next generation cost-effective vector control tools in the near future.

Keywords: Plant-based insect repellent, Ethnobotanical survey, Knowledge, Self-reported practice

\section{Background}

Insect-transmitted diseases cause over a million deaths and threaten hundreds of millions lives every year [1]. In the recent decades, the global warming, unplanned urbanization, and unchecked anthropogenic activities has contributed to the emergence and resurgence of many insect-borne diseases like malaria, filariasis, dengue fever,

\footnotetext{
*Correspondence: karunamoorthi@gmail.com

Unit of Medical Entomology and Vector Control, Department of

Environmental Health Sciences and Technology, College of Public Health \&

Medical Sciences, Jimma University, Jimma, Ethiopia
}

leishmaniasis, trypanosomiasis, and several Arbo-viral diseases [2]. Malaria is a life-threatening disease [3], and the malaria parasites are transmitted via mosquitoes. It remains as one of the leading public health issues in resource-poor settings of sub-Saharan Africa (SSA), Southeast Asian (SEA) countries and beyond [4]. The recent World Malaria Report [1] has estimated that in 2010 globally around half of the world population (approximately 3.3 billion people) has been at the risk of infection in 104 countries, and about 219 million clinical cases have been reported, It contributes to approximately 660,000 
deaths worldwide among which $91 \%$ of deaths occur in Africa alone.

It has been estimated that approximately $20-30 \%$ of all African malaria cases occur in Nigeria and Ethiopia alone [5]. Ethiopia is among the most malaria epidemicprone countries in sub-Saharan region. During the epidemic, the rates of morbidity and mortality are observed to raise dramatically (i.e. $3-5$ fold) [6]. Nearly 52 million of people (68\%) live in malarious areas [6]. It remains as a major cause of maternal and childhood morbidity and mortality [7] due to lesser immunity among the expectant mother and children than others [8]. It is a major impediment to socioeconomic development as the peak transmission season coincides with the usual planting and harvesting periods [9].

In Ethiopia, Anopheles arabiensis Patton is a predominant malaria vector, while An. funestus Giles, An. pharoensis Theobald, and $A n$. nili Theobald are the secondary vectors [10]. An. arabiensis has the ability, to adapt to all types of climatic features and in order to avoid insecticide treated surfaces, it can quickly adjust from endophagic to exophagic nature too. It is important to emphasize that though An. arabiensis biting occurs all through night, the peak man-biting activity begins in the early evening (19:00). It ultimately circumvents some of the protective effects of bed nets [11] and other personal protection interventions. In this context, repellent has a pivotal role to play on ensuring to minimize the insects hazard and disease transmission [12].

The repellent plant usage is intertwined with Africa's tradition and culture [13] for instance, in Eretria people just hang them around the bed, doors and windows [14], in Ethiopia and Kenya people burn or spray a number of plants to reduce the numbers of mosquitoes indoors at night [13,15-18]. In Ethiopia, burning of dried repellent plants is one of the common phenomena to drive away insects and mosquitoes. It is usually performed by using the traditional charcoal stove (thermal expulsion) in the early evenings. In the recent years, a revived interest has been observed among the health-conscious consumers with the plant-based repellents because of their low mammalian and non-target toxicity [17] than their synthetic counterparts. Consequently, the exploding demands and falling supply insists to conduct more ethnobotanical survey in order to formulate risks-reduced/ green pesticides and repellents from the traditionally used repellent plants.

The interaction between people and plants is called ethnobotany [19] and it is a tool to unlock the secrecy of indigenous knowledge and cultural practices for the well-being of mankind. Repellent plant usage custom has been developed, sustained and passed down to many generations within a community mostly through word of mouth [17]. The practical knowledge and practices often adapt or get modified according to the current needs too. Subsequently, these may contribute to distortion or gradual erosion of indigenous knowledge and cultural practices and therefore it has to be tapped properly. From these perspectives, the purpose of the present survey was to assess the knowledge and usage practices of repellent plants among the local inhabitants in a malariaepidemic prone area of Ethiopia. This spinoff research work could open the door to pick and choose a repellent plant among the countless promising candidates and to explore and develop long lasting and cost-effective vector control tools in the future.

\section{Materials and methods \\ Description of the ethnobotanical survey setting}

The ethnobotanical survey was conducted among the Bechobore kebele [village; (small local administrative unit in Ethiopia)], residents. It is one of the malarious areas in Jimma Zone, Kersa woreda (district), Oromia Regional State of Southwestern Ethiopia (Figure 1). It is located $356 \mathrm{~km}$ away from Addis Ababa, the federal capital of Ethiopia. The Oromo ethnic group is the most predominant one (81.2\%) and the majority of them are Muslims [20]. It is located at an altitude of $1755 \mathrm{~m}$ above sea level and the average annual rainfall and temperature is about $700 \mathrm{~mm}$ and $21^{\circ} \mathrm{C}$, respectively. Based on climatic conditions, the study area classified as one of the woienadega areas of Ethiopia, where malaria is holo and hyper-endemic (intense transmission) in nature. One health post and one middle school are located. The kebele is divided into seven zones for administrative purpose. Among them, three (i.e. Saxama, Sedecha and Tulama) zones are highly malarious where disease transmission occurs almost throughout the year.

Malaria is a major public health issue with more than $56 \%$ of clinical case incidences at household level (personal communication with the local Health Extension Worker (HEW) in April 2013). The local residents cultivate Teff (Eragrostis tef Zucc.), maize (Zea mays L.), barley (Hordeum vulgare L.), cereal such as sorghum (Sorghum bicolor L.), wheat (Triticum aestivum L.), etc. Besides, it is also renowned for the cultivation of the cash crop like Khat (Catha edulis Forsk.) and coffee (Coffea arabica L.) and raising live stocks. Boye river/wetland is running perennial along the entire study area and during the rainy season it creates a swampy or marshy area and more or less permanent large pools of water or small 'lakes', which serve as potential breeding sites for mosquitoes [21]. The greater majority of the houses are called traditional tukuls, built with mud and covered with a thatch roofs.

Due to the prolonged period of exposure to malaria, residents have traditionally been applying several plants as repellents to drive away blood-sucking insects, particularly mosquitoes. This practice is quite interlinked 




Figure 1 Location of the study area Bechobore kebele, Jimma Zone, Oromia region, Ethiopia.

with the centuries-old Ethiopian coffee ceremony. The present study setting (an Ethiopian region called, Kaffa) being the birthplace of the coffee plant, this ceremony is practiced by making coffee from a traditional charcoal stove, which is continuing to burn the traditional incenses. It lasts almost $40 \mathrm{~min}$ to $2 \mathrm{~h}$ by spreading of fresh aromatic grasses and/or flowers across the floor. In most parts of Ethiopia, the observance takes place three times a day - in the morning, at noon and evening. Therefore, we strongly believe that the repellent usage practices could have emerged from the Ethiopian coffee ceremony ritual.

\section{Study design and sampling technique}

The study was a community based cross-sectional survey conducted between January and May of 2013. A stratified, systematic random sampling was used for the selection of a total of 309 households from three (i.e.
Saxama, Sedecha and Tulama) zones of the Bechobore Kebele (village). 103 respondents were chosen from each of the selected zones. The sample size was calculated by employing 95\% confidence interval formula to estimate a population proportion.

\section{Interview}

The interview was carried out by involving selected 309 household members. In order to evaluate the clarity of the questionnaire, the validity of the instrument, and reactions of the respondents to the questionnaire a pretest was conducted prior to the actual data collection on $10 \%$ of the study population, i.e. about 31 residents by the enumerators, in an area different from the study area, but with the similar socio-demographic pattern. One adult from each selected household was interviewed on the knowledge and traditional uses of repellent plants, by administering a pre-tested questionnaire specifically 
designed for this purpose. Male and female respondents from all age-groups were included. To avoid biassing information and variables, the questionnaire has been prepared in the English language and has been translated into the local native language (Afan Oromo) in order to make it easy to understand and to administer by interviewers and interviewees.

\section{Ethics statement}

The study design and the consent process have been approved by the ethical clearance committee of the Jimma University, Ethiopia. Before the commencement of the survey, meetings with community health workers, community leaders and members of the neighbourhood associations were held in which the objectives of the survey were clearly explained. Since all the selected respondents were above eighteen-years of age, the informed written consent was obtained from each of the study participants prior to the interview, with the help of an approved voluntary consent form. Every participant was assured to withdraw the interview at any phase if they wish to do so. However, all the informants actively participated and no one declined to cease the interview. Study identification numbers were used instead of participant names and the information collected has been kept confidential. Feedback to the study population was conducted in the form of dissemination meetings after the completion of the survey.

\section{Ethnobotanical data collection}

A team of well-trained and closely supervised local interviewers conducted the household survey using a pretested questionnaire to interview with the representative of selected household. Interviewers collected information regarding socio-demographic and ethnobotanical data. Study participants were asked to impart their knowledge and usage custom on repellent plants. The main questions focused on (1) the usage and knowledge on IRPs, (2) names of plants used or known, (3) insects against which plants are used, (4) mode of applications, and (5) parts of the plant material used. Besides, the repellent plants have been categorized basis on their affordability, accessibility and efficiency for the assessment by employing the following criterion; (a) potentially useful (the plants potent enough to drive away insects' minimum of $60 \mathrm{~min}$ ), (b) accessible (the plants available within their neighbourhood without any serious efforts), and (c) affordable (the cost is within the range of 1-3 Ethiopian birr).

The authors also made personal observations in the field on the typical habitats and repellent plants collected by accompanying traditional users, translators and field assistants. Specimens of the reported plants were collected during the regular walk in the fields. The collected voucher specimens were pressed, numbered, dried, identified and deposited at the Jimma University Regional Herbarium and at The National Herbarium

Table 1 Study of respondents with gender, age, educational status, average monthly income, religion, ethnicity, family size and knowledge of insect repellent plants among the local inhabitants in the Becho Bore Kebele

\begin{tabular}{|c|c|c|}
\hline $\begin{array}{l}\text { Socio-demographic } \\
\text { characteristics variables }\end{array}$ & $\begin{array}{l}\text { Frequency } \\
(\mathrm{n}=309)\end{array}$ & Percent \\
\hline \multicolumn{3}{|l|}{ Gender } \\
\hline Male & 108 & 34.9 \\
\hline Female & 201 & 65.1 \\
\hline \multicolumn{3}{|c|}{ Age of respondents (in Years) } \\
\hline $19-30$ & 107 & 34.7 \\
\hline $31-40$ & 104 & 33.6 \\
\hline $41-50$ & 46 & 14.8 \\
\hline $51-60$ & 11 & 03.6 \\
\hline$\geq 60$ & 41 & 13.3 \\
\hline \multicolumn{3}{|l|}{ Occupational status } \\
\hline Peasant (Small farmers) & 50 & 16.2 \\
\hline Merchant & 57 & 18.4 \\
\hline Civil servants & 45 & 14.5 \\
\hline Student & 11 & 03.6 \\
\hline Housewife & 46 & 14.9 \\
\hline Daily labour & 52 & 16.9 \\
\hline Other & 48 & 15.5 \\
\hline \multicolumn{3}{|l|}{ Educational status } \\
\hline Illiterate & 67 & 21.7 \\
\hline Read write & 26 & 08.6 \\
\hline Grade 1-5 & 37 & 11.9 \\
\hline Grade 6-8 & 77 & 24.6 \\
\hline Grade 9-10 & 52 & 16.8 \\
\hline Grade 11-12 & 5 & 01.8 \\
\hline College \& Above & 45 & 14.6 \\
\hline \multicolumn{3}{|c|}{ Monthly income [Ethiopian Birr ( 1 USD = 19.7 Eth Birr)] } \\
\hline$<200$ & 25 & 08.1 \\
\hline $201-400$ & 148 & 47.8 \\
\hline $401-600$ & 42 & 13.5 \\
\hline $601-800$ & 68 & 22.1 \\
\hline$>800$ & 26 & 08.5 \\
\hline \multicolumn{3}{|c|}{ Knowledge on insect repellent plants $(n=309)$} \\
\hline Yes & 217 & 70.2 \\
\hline No & 92 & 29.8 \\
\hline \multicolumn{3}{|c|}{ Usage custom of insect repellent plants $(n=217)$} \\
\hline Yes & 199 & 91.8 \\
\hline No & 18 & 08.3 \\
\hline
\end{tabular}


Table 2 Information on insect repellent plants in relation with plant parts used, method of application and types of insects repelled

\begin{tabular}{|c|c|c|c|c|c|c|c|c|c|}
\hline S. No. & $\begin{array}{l}\text { Vernacular name } \\
\text { (Afaan Oromoo) }\end{array}$ & Family name & Plant Scientific name & Voucher No. & $\begin{array}{l}\text { UR } \\
(n=199)\end{array}$ & $(\%)^{a}$ & Plant Part(s) used & Method of application & Insect(s) control \\
\hline 1 & Dhumugaa & Acanthaceae & $\begin{array}{l}\text { Justicia } \\
\text { schimperiana T. }\end{array}$ & JER13 & 57 & 28.7 & Leaves & Burning to generate smoke. & $\begin{array}{l}\text { Mosquitoes } \\
\text { and coachroaches }\end{array}$ \\
\hline 2 & Qullubii adii & Alliaceae & $\begin{array}{l}\text { Allium sativum } \\
\text { Linn. }\end{array}$ & JER17 & 62 & 31.2 & Bulb & $\begin{array}{l}\text { Crushing and applying } \\
\text { the juice on the skin. }\end{array}$ & Mosquitoes \\
\hline 3 & Eebicha & Asteraceae & $\begin{array}{l}\text { Vernonia } \\
\text { amygdalina } \\
\text { Del. }\end{array}$ & JER8 & 71 & 35.7 & Leaves and barks & $\begin{array}{l}\text { Crushing the leaves } \\
\text { and apply the juice } \\
\text { on the exposed parts } \\
\text { of the body. }\end{array}$ & $\begin{array}{l}\text { Tick, mites } \\
\text { and mosquitoes }\end{array}$ \\
\hline 4 & Qabaaricho & Asteraceae & $\begin{array}{l}\text { Echinops kebericho } \\
\text { Mesfin. }\end{array}$ & JER15 & 60 & 30.2 & Root & $\begin{array}{l}\text { Dried parts burned to } \\
\text { generate smoke }\end{array}$ & Mosquitoes \\
\hline 5 & Fexo & Brassicaceae & $\begin{array}{l}\text { Lepidium sativum } \\
\text { Linn }\end{array}$ & JER12 & 51 & 25.7 & Seeds & $\begin{array}{l}\text { Crushing and applying } \\
\text { on skin also drinking }\end{array}$ & $\begin{array}{l}\text { Mosquitoes, housefly, } \\
\text { ticks and mites. }\end{array}$ \\
\hline 6 & Sanaficaa & Brassicaceae & $\begin{array}{l}\text { Brassica nigra Linn. } \\
\text { Koch }\end{array}$ & JER20 & 31 & 15.6 & Seeds & $\begin{array}{l}\text { Seed crushed and } \\
\text { its juice rubbed } \\
\text { on the body }\end{array}$ & Mosquitoes \\
\hline 7 & Qomonyoo & Buddlejaceae & $\begin{array}{l}\text { Buddleja polystachya } \\
\text { Fresen. }\end{array}$ & JER19 & 59 & 29.7 & Dermis of roots & $\begin{array}{l}\text { Burning the dried roots } \\
\text { to generate smoke. }\end{array}$ & Mosquitoes \\
\hline 8 & Ixanaa( nadii) & Burseraceae & $\begin{array}{l}\text { Boswellia papyrifera } \\
\text { (Del.) Hochst. }\end{array}$ & JER10 & 98 & 49.3 & Barks and Resin & $\begin{array}{l}\text { Burning to barks and } \\
\text { resin to generate smoke. }\end{array}$ & $\begin{array}{l}\text { Mosquitoes and } \\
\text { house fly }\end{array}$ \\
\hline 9 & Papayaa & Caricaceae & Carica papaya Linn. & JER2 & 56 & 28.2 & Leaves & $\begin{array}{l}\text { Crushing the dried } \\
\text { leaves and apply the } \\
\text { juice on the exposed } \\
\text { parts of the body. }\end{array}$ & Mosquitoes and ticks \\
\hline 10 & Bukbuka & Colchicaceae & $\begin{array}{l}\text { Colchicum autumnale } \\
\text { Linn. }\end{array}$ & JER1 & 53 & 26.7 & Barks/dermis & $\begin{array}{l}\text { Burning the dried } \\
\text { parts to generate smoke. }\end{array}$ & \\
\hline 11 & Gatirra Habasha & Cupressaceae & Cupressus lusitanica Mill. & JER6 & 143 & 71.9 & Leaves, dermis, barks & $\begin{array}{l}\text { Burning dried parts to } \\
\text { generate smoke. }\end{array}$ & $\begin{array}{l}\text { Mosquitoes and } \\
\text { house fly }\end{array}$ \\
\hline 12 & Bakanissa & Euphorbiaceae & $\begin{array}{l}\text { Croton macrostachyus } \\
\text { Hochst. ex Del. }\end{array}$ & JER4 & 87 & 43.8 & Leaves & $\begin{array}{l}\text { Burning the dried leaves } \\
\text { to generate smoke. }\end{array}$ & Mosquitoes \\
\hline 13 & Qobo & Euphorbiaceae & Ricinus communis Linn. & JER9 & 54 & 27.2 & Seeds & $\begin{array}{l}\text { Seed crushed and it } \\
\text { juices applied on the skin. }\end{array}$ & $\begin{array}{l}\text { Tick, mosquitoes, } \\
\text { and bedbugs }\end{array}$ \\
\hline 14 & Damakessie & $\begin{array}{l}\text { Lamiaceae } \\
\text { (alt. Labiatae) }\end{array}$ & $\begin{array}{l}\text { Ocimum lamiifolium } \\
\text { Hochst. ex Benth. }\end{array}$ & JER3 & 65 & 32.7 & Leaves & $\begin{array}{l}\text { Burning dried parts to } \\
\text { generate smoke, making } \\
\text { juice and applying on skin }\end{array}$ & Mosquitoes \\
\hline 15 & Qoricha michii & $\begin{array}{l}\text { Lamiaceae } \\
\text { (alt. Labiatae) }\end{array}$ & Ocimum suave Willd. & JER7 & 61 & 30.7 & $\begin{array}{l}\text { Growing plant nearby houses, } \\
\text { whole plant and leaves }\end{array}$ & $\begin{array}{l}\text { Burning dried parts to } \\
\text { generate smoke, making } \\
\text { juice and applying on skin }\end{array}$ & Mosquitoes \\
\hline 16 & Hincinnii & Malvaceae & Pavonia urens Cav. & JER16 & 47 & 23.7 & Leaves & Burning to generate smoke. & $\begin{array}{l}\text { Mosquitoes and } \\
\text { house fly }\end{array}$ \\
\hline 17 & Akaakltii adii & Myrtaceae & Eucalyptus globulus Labill & JER22 & 112 & 61.4 & Whole plant and leaves & $\begin{array}{l}\text { Burning whole plant } \\
\text { and crushing leaves }\end{array}$ & $\begin{array}{l}\text { Mosquitoes } \\
\text { and other }\end{array}$ \\
\hline
\end{tabular}


Table 2 Information on insect repellent plants in relation with plant parts used, method of application and types of insects repelled (Continued)

\begin{tabular}{|c|c|c|c|c|c|c|c|c|c|}
\hline & & & & & & & & $\begin{array}{l}\text { and applying on } \\
\text { exposed body parts }\end{array}$ & $\begin{array}{l}\text { haematophagous } \\
\text { insects }\end{array}$ \\
\hline 18 & Bargamoo adii & Myrtaceae & Eucalyptus citriodora Hook. & JER11 & 59 & 29.7 & Leaves & $\begin{array}{l}\text { Crushing and applying } \\
\text { on skin and burning } \\
\text { to generate smoke. }\end{array}$ & $\begin{array}{l}\text { Mosquitoes, } \\
\text { coachroaches, } \\
\text { ticks and house fly }\end{array}$ \\
\hline 19 & Ejersaa & Oleaceae & Olea europaea Linn. & JER18 & 58 & 29.1 & $\begin{array}{l}\text { Leaves } \\
\text { and parks }\end{array}$ & $\begin{array}{l}\text { Dried parts burned } \\
\text { to generate smoke. }\end{array}$ & $\begin{array}{l}\text { Mosquitoes } \\
\text { and house fly }\end{array}$ \\
\hline 20 & Qolaa burtukanaa & Rutaceae & Citrus sinensis (L.) Osb. & JER21 & 69 & 34.7 & Peals & $\begin{array}{l}\text { Dried peels burned } \\
\text { to generate smoke }\end{array}$ & $\begin{array}{l}\text { Mosquitoes } \\
\text { and house fly }\end{array}$ \\
\hline 21 & Lommii & Rutaceae & $\begin{array}{l}\text { Citrus aurantifolia } \\
\text { (Christm.) }\end{array}$ & JER14 & 24 & 12.1 & Peels of fruits & $\begin{array}{l}\text { Crushing and applying } \\
\text { on exposed parts of } \\
\text { the body. }\end{array}$ & Mosquitoes \\
\hline 22 & Hargessa dhala & Xanthorrhoeaceae & $\begin{array}{l}\text { Aloe pulcherrima } \\
\text { M.G. Gilbert } \\
\text { \& Sebsebe. }\end{array}$ & JER5 & 66 & 33.2 & Leaves & $\begin{array}{l}\text { Burning the dried } \\
\text { leaves to generate } \\
\text { smoke and crushing } \\
\text { leaves to spray in } \\
\text { and around houses. }\end{array}$ & Tick and mosquitoes \\
\hline 23 & Shita $^{b}$ & NA & NA & NA & 43 & 21.7 & $\begin{array}{l}\text { Churn of } \\
\text { several } \\
\text { repellent } \\
\text { plant parts }\end{array}$ & Smoking and spray & $\begin{array}{l}\text { Mosquitoes } \\
\text { and other } \\
\text { haematophagous insects }\end{array}$ \\
\hline
\end{tabular}

Note: NA: the relevant information is not available.

UR: (use-record) the number of the respondents who claimed the use of specific plant as an insect repellent

apercent does not add up to 100 , because of multiple responses.

${ }^{\mathrm{b}}$ Shita is a mixture of various traditional repellent plant parts such as stem, root, resin, leaves and bark. It is widely available in the marketplace in the majority of the Ethiopian towns. 


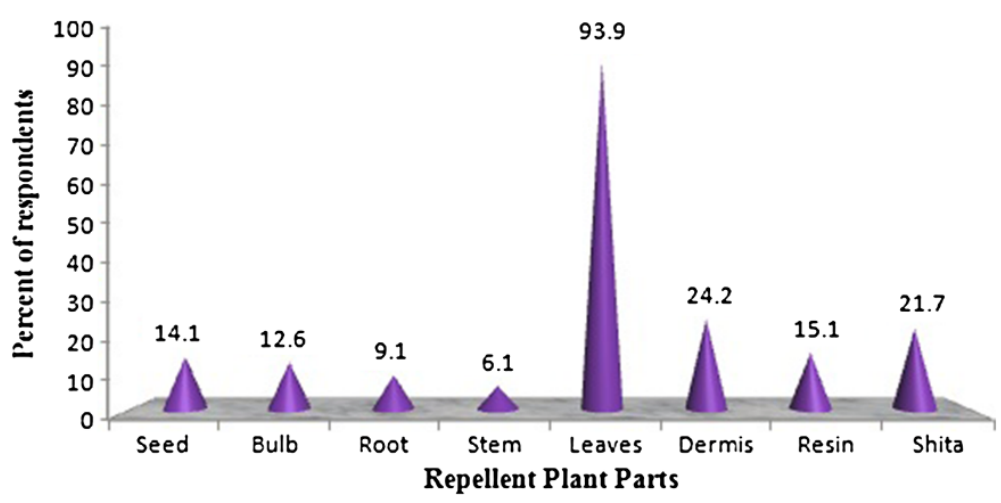

Figure 2 Parts of repellent plants used by the community to drive-away different types of medically important insects and mosquitoes. Note: Percent does not add up to 100, because of multiple responses.

(ETH) in Addis Ababa University. Identification of specimens was done with the help of herbarium materials, experts and taxonomic keys in the Flora of Ethiopia and Eritrea [22-28].

\section{Data management and analysis}

In the field, data were collected in a standardized questionnaire and data collection forms and checked for errors and completeness. Data was then counterchecked before entry into DbaseV (Borland International, Scotts Valley, California, USA) using the double entry system. Summary statistics were performed using STATA version 10 (STATA Corp., Texas, USA). The range and mean were analyzed and appropriate tables, graphs and percentage details were displayed. The chi-square analysis was performed to test the hypothesis. The level of significance was also determined by using $95 \%$ of confidence intervals and $P$-value.

\section{Results and discussion}

\section{Socio-demographic characteristics of respondents}

The socio-demographic characteristics of the study respondents are shown in the Table 1 Overall, 70.2\%(217/309) of the local inhabitants have had ample awareness, nevertheless, 91.8\%(199/217) of them were applying these plants as insect repellents (Table 1). It is important to note that though the survey has been conducted by involving 309 eligible respondents, only 217 of them have had awareness on insect repellent plants accordingly the level of awareness was 70.2\%. However, out of 217 knowleged residents 199 of them were using (91.8) these plants as insect repellents.

\section{Knowledge on traditional insect repellent plants}

Respondents cited overall 23 plants as insect repellents to repel insects, principally mosquitoes (Table 2). Nevertheless, one of the most renowned traditional fish poisoning plants called Birbira [vernacular name (local native language, Amharic); Milletia ferruginea] was cited by three study participants by mistake as insect repellent. Consequently, this plant was excluded and finally all the known 22 species were compiled in the Table 2. Interestingly $21.7 \%(43 / 199)$ of the respondents were using Shita (a mixture of various repellent plants stem, root, resin, leaves and bark) which is abundantly available in most of the Ethiopian towns. It is mainly prepared by the folk with approximately $5 \mathrm{~g}$ of repellent plant materials wrapped in a plastic paper and commercialized.

\section{Common mosquito avoiding self-reported practices and perception}

The greater majority of the study participants driveaway the insects by smoldering [98.9\% (197/199)] the dried leaves $[93.9 \%(187 / 199)]$ in the early evening to minimize man-vector contact (Figure 2). Overall, 85.5\%, $86.8 \%$ and $83.9 \%$ of the respondents consider that these plants are extremely useful, accessible and affordable, respectively (Table 3 ). About $52.8 \%$ of the local residents were applying approximately $15 \mathrm{~g}$ of dried plant-products every day (Figure 3). The association between respondent's knowledge and self-reported usage practices of repellent plants with their age, gender, monthly income and educational status were tested with chi-square analysis and the results are given in Table 4.

This survey is intended to shed the limelight to showcase the Ethiopian people ethnobotanical knowledge and their insects avoiding practices in one of the malaria epidemic-prone settings. It is important to note that the level of awareness is relatively lower when compare with the several prior Ethiopian studies conducted in Addis Zemen town (97.2\%) [16], Kofe kebele (83.6\%) [17], and the Western Hararghe Zone (92.1\%) [18]. It could be possibly explained that though the present survey was conducted in the rural setting, it is located in close proximity of the Jimma town. Therefore, the residents might 
Table 3 Perception of the study participants regarding the traditional insect repellent plants accessibility, affordability, effectiveness and self reported plant specieses, which are scientifically reported and authenticated as insect repellent plants

\begin{tabular}{|c|c|c|c|c|c|c|c|c|c|c|}
\hline \multirow[t]{2}{*}{ S. No. } & \multirow[t]{2}{*}{ Scientific name } & \multicolumn{2}{|c|}{ Respondents using } & \multicolumn{2}{|c|}{$\begin{array}{c}\text { Is it } \\
\text { potentially useful? }\end{array}$} & \multicolumn{2}{|c|}{$\begin{array}{c}\text { Is it } \\
\text { accessible? }\end{array}$} & \multicolumn{2}{|c|}{$\begin{array}{c}\text { Is it } \\
\text { affordable? }\end{array}$} & \multirow[t]{2}{*}{ Previously reported or authenticated. } \\
\hline & & $\begin{array}{l}\text { UR } \\
(n=199)\end{array}$ & Percent $^{\mathrm{a}}$ & $\overline{\text { Yes }}$ & No & $\overline{\text { Yes }}$ & No & Yes & No & \\
\hline 1. & Allium sativum & 62 & 31.2 & 85.4 & 14.6 & 80.6 & 19.4 & 88.7 & 11.3 & Valerio and Maroli, [29] \\
\hline 2. & Aloe pulcherrima & 66 & 33.2 & 93.9 & 06.1 & 78.7 & 21.3 & 68.1 & 31.9 & Bekele et al., [30] \\
\hline 3. & Boswellia papyrifera & 98 & 49.3 & 65.9 & 34.1 & 86.8 & 13.2 & 75.5 & 24.5 & Karunamoorthi et al., [17] \\
\hline 4. & Brassica nigra & 31 & 15.6 & 80.6 & 19.4 & 74.1 & 25.9 & 93.5 & 06.5 & Bekele et al., [30] \\
\hline 5. & Buddleja polystachya & 59 & 29.7 & 88.1 & 11.9 & 84.7 & 15.3 & 77.9 & 22.1 & NA \\
\hline 6. & Carica papaya & 56 & 28.2 & 78.6 & 21.4 & 85.8 & 14.2 & 92.8 & 07.2 & Kazembe et al., [31]; Rawani et al., [32] \\
\hline 7. & Citrus aurantifolia & 24 & 12.1 & 87.6 & 12.4 & 75.1 & 24.9 & 83.4 & 16.6 & NA \\
\hline 8. & Citrus sinensis & 69 & 34.7 & 84.1 & 15.9 & 94.2 & 05.8 & 89.9 & 10.1 & Zewde and Jembere, [33] \\
\hline 9. & Colchicum autumnale & 53 & 26.7 & 92.4 & 07.6 & 88.7 & 11.3 & 79.2 & 20.8 & NA \\
\hline 10. & Croton macrostachyus & 87 & 43.8 & 68.9 & 31.1 & 83.9 & 16.1 & 72.4 & 27.6 & Karunamoorthi and Ilango, [3] \\
\hline 11. & Cupressus lusitanica & 143 & 71.9 & 81.9 & 18.1 & 78.3 & 21.7 & 94.4 & 05.6 & Karunamoorthi et al., [17] \\
\hline 12. & Echinops kebericho & 60 & 30.2 & 88.3 & 11.7 & 95.1 & 4.9 & 90.1 & 09.9 & Karunamoorthi et al., [15] \\
\hline 13. & Eucalyptus citriodora & 59 & 29.7 & 89.9 & 10.1 & 84.7 & 15.3 & 81.3 & 18.7 & Palsson and Jaenson, [29] \\
\hline 14. & Eucalyptus globulus & 112 & 61.4 & 85.8 & 14.2 & 99.1 & 00.9 & 93.7 & 06.3 & Kweka et al., [34]; Palsson and Jaenson, [29] \\
\hline 15. & Justicia schimperiana & 57 & 28.7 & 92.9 & 07.1 & 87.8 & 12.2 & 80.8 & 19.2 & NA \\
\hline 16. & Lepidium sativum & 51 & 25.7 & 90.1 & 09.9 & 96.1 & 03.9 & 74.5 & 25.5 & Karunamoorthi and Husen, [18] \\
\hline 17. & Ocimum lamiifolium & 65 & 32.7 & 83.1 & 16.9 & 92.3 & 07.7 & 95.3 & 04.7 & Bekele et al., [30] \\
\hline 18. & Ocimum suave & 61 & 30.7 & 83.7 & 16.3 & 90.1 & 09.9 & 78.6 & 21.4 & Kweka et al., [34]; Seyoum et al., [13]; \\
\hline 19. & Olea europaea & 58 & 29.1 & 84.4 & 15.6 & 89.7 & 10.3 & 87.9 & 12.1 & Karunamoorthi et al., [15] \\
\hline 20. & Pavonia urens & 47 & 23.7 & 93.7 & 06.3 & 89.3 & 10.7 & 80.9 & 19.1 & NA \\
\hline 21. & Ricinus communis & 54 & 27.2 & 88.9 & 11.1 & 92.5 & 07.5 & 83.3 & 16.7 & Bekele et al., [30] \\
\hline 22. & Vernonia amygdalina & 71 & 35.7 & 84.6 & 15.4 & 78.8 & 21.2 & 84.5 & 15.5 & Onunkun, [35] \\
\hline 23. & Shita $^{\mathrm{b}}$ & 43 & 21.7 & 95.4 & 04.6 & 88.4 & 11.6 & 81.4 & 18.6 & Karunamoorthi and Husen, [18] \\
\hline Total & & & & 1968.2 & 331.8 & 1994.8 & 305.2 & 1928.1 & 371.9 & \\
\hline Percent & & & & 85.5 & 14.5 & 86.8 & 13.2 & 83.9 & 16.1 & \\
\hline
\end{tabular}

Note: UR: (use-record) the number of the respondents who claimed the use of plant as an insect repellent

${ }^{\text {aPercent }}$ does not add up to 100 , because of multiple responses.

${ }^{b}$ Shita is a mixture of various traditional repellent plant parts such as stem, root, resin, leaves and bark. It is widely available in the marketplace in the majority of the Ethiopian towns.

NA: Not available.

have greater access to procure other modern personal protective tools.

Traditional Knowledge (TK) is built upon the longterm experiences and trial or error close observation by the local communities. However, over the past decades a steady decline of TK has been reported worldwide [36-38]. It is attributable to that the majority of resourceful persons often elders are not willing to impart their knowledge to others except for their eldest son or the other next of kin in order to maintain the secrecy [39]. Besides, the younger generation does not have shown up enough interest to learn/know about the value of traditional repellent/medicinal plants. Therefore, every effort must be done to protect, preserve, promote, and practice our TK for the betterment of mankind.

Though residents have a low-level of awareness they were using 22 repellent plants (Table 2) than the previous Ethiopian ethnobotanical surveys that have reported a maximum of just 14 plant species [16-18]. Since the study area is well-known for the diversity of various plant species, it provides an ideal opportunity for local residents to apply several plants as these are easily accessible and freely available almost throughout the year [17]. Interestingly, the majority of plants cited by the respondents have been reported and scientifically authenticated formerly by several researchers [3,13-15,29-35,40] 


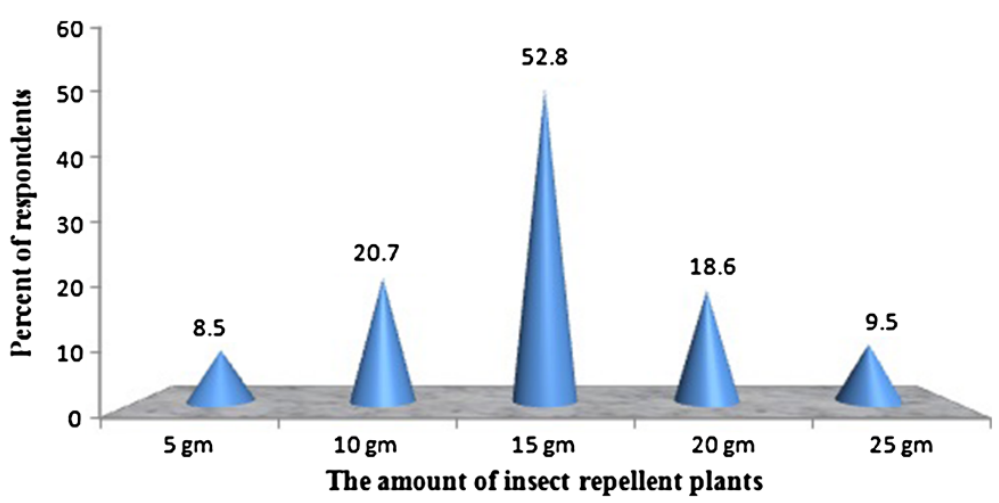

Figure 3 The amount of insect repellent plants used by the community repel different types of insects and mosquitoes.

as potent repellent and insecticidal agents against various insects, chiefly mosquitoes (Table 2). It evidently suggests that the local residents are gifted with sound knowledge and aptly applying these plants as repellents. The plant kingdom is a potential warehouse to identify several potential eco-user-friendly insect repellent/insecticides in the future. Ethiopia remains regardded as a repository of repellent plants owing to its varied climatic and topographic features [16-18].

Burning/smouldering of the dried leaves was the most common practice to prevent insects' nuisance (Table 2 and Figure 2). The findings are quite concurrent with the numerous previous studies conducted in Ethiopia [16-18], Eritrea [14] and Guatemala [41]. Seyoum et al., [13] reported that almost all the Kenyans have the custom of burning plants to repel mosquitoes. In Guinea Bissau, $55 \%$ of people burn plants to repel mosquitoes [40]. The result is also comparable to a study reported by Kweka et al., [34]. The use of plant leaves as insect repellent could be one of more sustainable options than any other parts like roots, resin and bark. This mode of application might not disrupt the natural plant growth as well as it shall supply the leaves throughout the year too [18].

The finding indicates that great majority of the inhabitants apply repellant plants in the early evenings (Figure 3). It could be possibly explained that this happens since the peak biting activity of local malaria vector $A n$. arabiensis begins in the dusk hours before people confined with bed nets or other means of interventions [42]. Subsequently residents urge to use repellents in the evenings to evade

Table 4 Knowledge and usage custom of insect/mosquito repellent plants in relation with gender, age and monthly income of the respondents

\begin{tabular}{|c|c|c|c|c|c|c|c|}
\hline \multirow[t]{2}{*}{ Variables } & \multirow{2}{*}{$\begin{array}{l}\text { Number of } \\
\text { respondents }\end{array}$} & \multicolumn{2}{|c|}{ Knowledge on insect repellent plants } & \multirow[t]{2}{*}{$P$ - value } & \multicolumn{2}{|c|}{ Insect repellent usage practices } & \multirow[t]{2}{*}{$P$ - value } \\
\hline & & Yes $(n=217)$ & No $(n=92)$ & & Yes $(n=199)$ & No $(n=18)$ & \\
\hline Gender & & & & $P-0.0209^{*}$ & & & $P-0.4420$ \\
\hline Female & 201 & 150 & 51 & $x^{2}=5.326$ & 139 & 11 & $x^{2}=0.591$ \\
\hline Male & 108 & 67 & 41 & $d f=1$ & 60 & 07 & $d f=1$ \\
\hline \multicolumn{8}{|c|}{ Age (Years) } \\
\hline $18-30$ & 107 & 76 & 31 & $P-0.9979$ & 69 & 07 & $P-0.8799$ \\
\hline $31-40$ & 104 & 72 & 32 & $x^{2}=0.13$ & 67 & 05 & $x^{2}=1.189$ \\
\hline $41-50$ & 46 & 32 & 14 & $d f=4$ & 29 & 03 & $d f=4$ \\
\hline $51-60$ & 11 & 08 & 03 & & 8 & 00 & \\
\hline$>60$ & 41 & 29 & 12 & & 26 & 03 & \\
\hline \multicolumn{8}{|c|}{ Average monthly income [Ethiopian Birr (1 USD = 19.7 Eth Birr] } \\
\hline$<200$ & 25 & 18 & 07 & $P-0.0226^{*}$ & 16 & 02 & $P-0.9912$ \\
\hline $201-400$ & 148 & 111 & 37 & $x^{2}=11.375$ & 102 & 09 & $x^{2}=0.277$ \\
\hline $401-600$ & 42 & 29 & 13 & $d f=4$ & 27 & 02 & $d f=4$ \\
\hline $601-800$ & 68 & 48 & 20 & & 44 & 04 & \\
\hline$>801$ & 26 & 11 & 15 & & 10 & 01 & \\
\hline
\end{tabular}

Note: ${ }^{*} \mathrm{P}<0.05$ statistically significant. 
the insect's menace and disease transmission. Respondents indicated that these plants are potentially useful, readily accessible and affordable too (Table 3). The findings are in accord with the previous Ethiopian [16-18] and Tanzanian surveys [34], where the majority of the local residents acknowledge that the existing synthetic repellents are not only expensive but also cause dangerous adverse effects than the repellent plants. The studies conducted in Guinea Bissau and Kenya also reported that the majority of the villagers prefer IRPs owing to lack of purchasing power $[41,43]$. We have personally witnessed and experienced that the Ethiopian IRPs are rationally effective and amiable to apply too.

A chi-square analysis shows a strong association between the respondents' knowledge on insect repellent plants and the gender $(P$ - value $=0.0209)$, and average monthly income $(P$ - value $=0.0226)$ (Table 4$)$. The findings are quite consistent with the previous Ethiopian studies [16-18]. However, there was no significant association found between the respondents' knowledge on TIRPs and their age $(P$ - value $=0.9979)$. Result is comparable with the previous studies conducted in Ethiopia with reference to age and knowledge on IRPs [16-18]. It could be possibly explained that since the usage of IRPs is one of the most common practices in the study setting, the residents might have acquired adequate awareness irrespective of their age. Chi-square analysis shows that the repellent plants usage custom is not significantly associated with gender $(P$ - value $=0.4420)$, age $(P$ - value $=0.8799)$, and monthly income $(P$ - value $=0.9912)$ of the respondents $($ Table 4$)$. It is likely due to the widespread usage of insect repellent plants and long-standing age-old practice and custom. Results are consistent with the earlier studies, which have reported that there is no significant relationship between the age, monthly income of respondents' and repellent plant usage custom [16-18].

At the moment, there is a revived interest has been observed both among the researchers and general public towards plant-based products attributable to their userand-eco-friendly nature. It earns more interest as the majority of the commercialized mosquito repellent products are derived from the well-known pyrethrum (Golden Flower) plant [Asteraceae; Chrysanthemum cinerariaefolium (current species name: Tanacetum cinerariifolium)] from East Africa [44]. Numerous widely-known repellent plants are in use by the indigenous rural people in the SSA countries, though they are quite unaware of the complete elucidation of the mechanism of repellency of those plants [44].

\section{Conclusion}

Arthropods not only serve as disease-transmitters but also cause considerable annoyance in terms of nuisance or menace to the householder. Consequently, in resource-limited settings like Ethiopia people have been applying several repellent plants to repel insects. Ethnobotanical surveys serve as a connecting-link to transfer the practical knowledge and traditional practices from the older to younger generations. It includes basic documentation and quantitative evaluation of the traditional uses of plants as nutraceuticals, and as insect repellents.

The usage of IRPs is a deep-rooted tradition and cultural heritage in Ethiopia. Present survey findings evidently suggest that there is a steady decline/erosion of knowledge and practices of repellent plants. It may be though this survey was conducted in the rural setting, it is located in close proximity of the Jimma town. Therefore, residents might have procured modern personal protection tools than traditional insect repellent plants. Nevertheless, cultural knowledge and traditional practices on insect repellent plants still much more to offer for the humankind. Therefore, it emphasizes on pursuing more ethnobotanical surveys for the proper documentation and preservation of indigenous knowledge and cultural practices. Besides, further studies are required to be warranted to identify and evaluate the responsible bioactive molecules. In addition, measuring their mammalian toxicity is also inevitable [34]. It could lay the first stone to devise affordable user-friendly next generation vector control tools to minimize the vector-borne disease burden especially malaria in the near future.

\section{Competing interests}

The authors declare that they have no competing interests.

\section{Authors' contributions}

The ethnobotanical survey was initiated by TH and KK. Data was consolidated, interpreted and analyzed retrospectively and independently by $\mathrm{KK}$ and $\mathrm{TH}$. KK and $\mathrm{TH}$ wrote the manuscript. KK revised the final manuscript. Both authors read and approved the final manuscript.

\section{Acknowledgements}

The authors sincerely would like to acknowledge Jimma University Research \& Publication Division for pursuing this research work by providing financial support. We are very much grateful to the study participants who shared their knowledge on the usage custom of repellent plants. Without their contribution, this study would have been impossible. The authors would like to acknowledge Ms. L. Melita for her sincere assistance in editing the manuscript. Our last but not least heartfelt thanks go to our colleagues from the School of Environmental Health Science, Faculty of Public Health, Jimma University, Jimma, Ethiopia, for their kind support and cooperation.

Received: 28 October 2013 Accepted: 9 February 2014

Published: 12 February 2014

\section{References}

1. World Malaria Report WHO: World Health Organization. Geneva: Switzerland; 2012.

2. Karunamoorthi K: Yellow Fever Encephalitis: An Emerging and Resurging Global Public Health Threat in a Changing Environment. In Encephalitis. Edited by Sergey T. InTech Publisher; 2013. Available from: http://www. intechopen.com/books/encephalitis/yellow-fever-encephalitis-an-emergingand-resurging-global-public-health-threat-in-a-changing-enviro. ISBN 978953-51-0925-9.

3. Karunamoorthi K, llango K: Larvicidal activity of Cymbopogon citratus (DC) Stapf. and Croton macrostachyus Del. against Anopheles arabiensis Patton 
(Diptera: Culicidae), the principal malaria vector. Eur Rev Med Pharmacol Sci 2010, 14(1):57-62

4. Karunamoorthi K: Global Malaria Eradication: Is It Still Achievable and Practicable? In Malaria: Etiology, Pathogenesis and Treatments. Edited by Anna Margrét P, Gerald E. 400 Oser Ave, Suite 1600 Hauppauge, New York 11788-3619 USA: Calamandrei. Nova Science Publishers, Inc; 2012a. Available at: https://www.novapublishers.com/catalog/product_info.php? products id=28842. ISBN 978-1-62100-401-1.

5. The Carter Center: Summary proceedings $3^{\text {rd }}$ annual malaria control program review. Ethiopia and Nigeria.The Carter Center, Atlanta, Georgia 30307, United States; 2012

6. $\mathrm{FMOH}$ (Federal Ministry Of Health Ethiopia): Malaria Operational Plan Ethiopia. Addis ababa, Ethiopia: President's Malaria Initiative; 2012.

7. Karunamoorthi K, Deboch B, Tafere Y: Knowledge and practice concerning malaria, insecticide-treated net (ITN) utilization and antimalarial treatment among pregnant women attending specialist antenatal clinics. J Pub Health 2010, 18(6):559-566.

8. Karunamoorthi K: Global malaria burden: socialomics implications. J Socialomics 2012, 1:e108. doi: 10.4172/jsc.1000e108.

9. Karunamoorthi K, Bekele M: Prevalence of malaria from peripheral blood smears examination: a 1-year retrospective study from the Serbo Health Center, Kersa Woreda, Ethiopia. Infect Pub Health 2009, 2(4):171-176.

10. Karunamoorthi $\mathrm{K}$, Yirgalem A: Insecticide risk indicators and occupational insecticidal poisoning in indoor residual spraying. Health Scope 2013, 1 (4):166-173. doi: 10.5812/jhs.8344.

11. Fornadel CM, Norris LC, Glass GE, Norris DE: Analysis of Anopheles arabiensis blood feeding behavior in southern Zambia during the two years after introduction of insecticide-treated bed nets. Am J Trop Med Hyg 2010, 83(4):848-853. doi: 10.4269/ajtmh.2010.10-0242.

12. Karunamoorthi K, Sabesan S: Laboratory evaluation of Dimethyl phthalate treated wristbands against three predominant mosquito (Diptera: Culicidae) vectors of disease. Eur Rev Med Pharmacol Sci 2010, 14(5):443-448

13. Seyoum A, Palsson K, Kung'a S, Kabiru EW, Lwande W, Killeen GF, Hassanali A, Knols BG: Traditional use of mosquito-repellent plants in western Kenya and their evaluation in semi-field experimental huts against Anopheles gambiae: ethnobotanical studies and application by thermal expulsion and direct burning. Trans R Soc Trop Med Hyg 2002, 96:225-231.

14. Waka M, Hopkins RJ, Curtis C: Ethnobotanical survey and testing of plants traditionally used against hematophagous insects in Eritrea. J Ethnopharmacol 2004, 95:95-101.

15. Karunamoorthi K, Mulelam A, Wassie F: Laboratory evaluation of traditional insect/mosquito repellent plants against Anopheles arabiensis, the predominant malaria vector in Ethiopia. Parasitol Res 2008, 103(3):529-534.

16. Karunamoorthi K, Mulelam A, Wassie F: Assessment of knowledge and usage custom of traditional insect/mosquito repellent plants in Addis Zemen Town, South Gonder, North Western Ethiopia. J Ethnopharmacol 2009, 1121(1):49-53.

17. Karunamoorthi K, llango K, Endale A: Ethnobotanical survey of knowledge and usage custom of traditional insect/mosquito repellent plants among the Ethiopian Oromo ethnic group. J Ethnopharmacol 2009, 125(2):224-229.

18. Karunamoorthi K, Husen E: Knowledge and self-reported practice of the local inhabitants on traditional insect repellent plants in Western Hararghe Zone, Ethiopia. J Ethnopharmacol 2012, 141(1):212-219. doi:10.1016/j.jep.2012.02.022.

19. Schultes RE: Ethnobotany and technology in the Northwest Amazon: A partnership. In Sustainable harvest and marketing of rain forest products. Edited by Plotkin and Famolare. CA: Island Press; 1992:pp: 45-pp: 76.

20. CSA (Central Statistical Agency): The Ethiopian Demographic and Health Survey 2005. Addis Ababa, Ethiopia: Ethiopian Central Statistical Agency; 2006.

21. Ambelu A, Mekonen S, Silassie AG, Malu A, Karunamoorthi K: Physicochemical and biological characteristics of Two Ethiopian wetlands. Wetlands 2013, 33(4):691-698. doi: 10.1007/s13157-013-0424-y.

22. Edwards S, Demissew S, Hedberg I: Flora of Ethiopia and Eritrea Hydrocharitaceae to Arecaceae, Volume 6. Addis Ababa, Ethiopia, and Department of Systematic Botany, Uppsala, Sweden: The National Herbarium; 1997.

23. Edwards S, Tadesse M, Demissew S, Hedberg I: Flora of Ethiopia and Eritrea Magnoliaceae to Flacourtiaceae, Volume 2. Addis Ababa, Ethiopia, and Department of Systematic Botany, Uppsala, Sweden: The National Herbarium; 2000
24. Edwards S, Tadesse M, Hedberg I: Flora of Ethiopia and Eritrea Canellaceae to Euphorbiaceae, Volume 2. Addis Ababa, Ethiopia, and Department of Systematic Botany, Uppsala, Sweden: The National Herbarium; 1995.

25. Hedberg I, Edwards S: Flora of Ethiopia and Eritrea Pittosporaceae to Araliaceae, Volume 3. Addis Ababa, Ethiopia, and Department of Systematic Botany, Uppsala, Sweden: The National Herbarium; 1989.

26. Hedberg I, Edwards S: Flora of Ethiopia and Eritrea Poaceae, Volume 7. Addis Ababa, Ethiopia, and Department of Systematic Botany, Uppsala, Sweden: The National Herbarium; 1995.

27. Hedberg I, Edwards S, Nemomissa S: Flora of Ethiopia and Eritrea Apiaceae to Dipsacaceae, Volume 4. Addis Ababa, Ethiopia, and Department of Systematic Botany, Uppsala, Sweden: The National Herbarium; 2003.

28. Hedberg I, Friis I, Edwards S: Flora of Ethiopia and Eritrea Asteraceae, Volume 4. Addis Ababa, Ethiopia, and Department of Systematic Botany, Uppsala, Sweden: The National Herbarium; 2004.

29. Valerio L, Maroli M: Evaluation of repellent and anti-feeding effect of garlic oil (Allium sativum) against the bite of phlebotomine sandflies diptera: psychodidae. Ann Ist Super Sanita 2005, 41(2):253-256.

30. Bekele D, Asfaw Z, Petros B, Tekie H: Ethnobotanical study of plants used for protection against insect bite and for the treatment of livestock health problems in rural areas of Akaki istrict, Eastern Shewa, Ethiopia. Topcls J Herbal Med 2012, 1(2):12.

31. Kazembe T, Makusha C: Evaluation of mosquito repellencies of Capsicum frutescens, Carica papaya and Cyanodondactylon extracts and extract mixtures. Bull Environ Pharmacol Life Sci 2012, 1:34-40.

32. Rawani A, Ghosh A, Laskar S, Chandra G: Aliphatic amide from seeds of carica papaya as mosquito larvicide, pupicide, adulticide, repellent and smoke toxicant. J Mosa Res 2012, 2:8-18.

33. Zewde DK, Jembere B: Evaluation of orange peel citrus sinensis $(L)$ as a source of repellent, toxicant and protectant against Zabrotes subfasciatus (Coleoptera: bruchidae). Momona Ethiopian J Sci 2010, 2(1):61-75.

34. Kweka EJ, Mosh F, Lowassa A, Mahande AM, Kitau J, Matowo J: Ethnobotanical study of some of mosquito repellent plants in north-eastern Tanzania. Mal J 2008, 7:152. doi: 10.1186/1475-2875-7-152.

35. Onunkun O: Studies on the repellent activities of four common asteraceae in Nigeria against Red flour beetle, tribolium castaneum. Intl J Eng Sci 2013, 2(12):90-93.

36. Brockman A, Masuzumi B, Augustine S: When all people have the same story, human will Cease to Exist. Dene Cultural Institute: Protecting and Conserving Traditional Knowledge. A Report for the Biodiversity Conservation Office; 1997.

37. Twang S, Kapoor P: Protecting and Promoting Traditional Knowledge: Systems, National Experiences and International Dimensions. In United Nations Conference on Trade and Development (UNCTAD) United Nations. New York and Geneva: United Nations; 2004

38. Karunamoorthi K, Sabesan S, Jegajeevanram K, Vijayalakshmi J: The role of traditional anti-malarial plants in the battle against global malaria burden. Vector-Borne Zoon Dis 2013, 13(8):521-544. Doi: 10.1089/vbz.2011.0946.

39. Karunamoorthi K, Tsehaye E: Ethnomedicinal knowledge, belief and self-reported practice of local inhabitants on traditional antimalarial plants and phytotherapy. J Ethnopharmacol 2012, 141(1):143-150. Doi:10.1016/j.jep.2012.02.012.

40. Palsson $\mathrm{K}$, Jaenson TG: Plant products used as mosquito repellents in Guinea Bissau, West Africa. Acta Trop 1999, 72:39-52.

41. Klein RE, Weller SC, Zeissig R, Richards FO, Ruebush TKN: Knowledge, beliefs, and practices in relation to malaria transmission and vector control in Guatemala. Am J Trop Med Hyg 1995, 52:383.

42. Karunamoorthi K, Sabesan S: Insecticide resistance in insect vectors of disease with special reference to mosquitoes: a potential threat to global public health. Health Scope 2013, 2(1):4-18. Doi: 10.5812/jhs.9840,

43. Odalo JO, Omolo MO, Malebo H, Angira J, Njeru PM, Ndiege IO, Hassanali A: Repellency of essential oils of some plants from the Kenyan coast against Anopheles gambiae. Acta Trop 2005, 2005(3):210-218.

44. Karunamoorthi K: Plant-based insect repellents: is that a sustainable option to curb the malaria burden in Africa? J Med Aromatic Plants 2012, 1:e106. doi: 10.4172/map.1000e106.

doi:10.1186/1746-4269-10-22

Cite this article as: Karunamoorthi and Hailu: Insect repellent plants traditional usage practices in the Ethiopian malaria epidemic-prone setting: an ethnobotanical survey. Journal of Ethnobiology and Ethnomedicine 2014 10:22. 